\title{
Living Streams of World Literature
}

\author{
LAURI PILTER
}

\section{Gerald Gillespie, Living Streams: Continuity and Change from Rabelais to Joyce. Nouvelle poétique comparatiste, Vol. 40. Brussels: P. I. E. PETER LANG S. A., 2018. 207 pages.}

Gerald Gillespie, born in 1933, is a retired professor of German language and literature and of comparative literature of Stanford University. His earliest publications date from the mid-1950s. For decades, he has been an outstanding member of International Comparative Literature Association. From 1994 to 1997, he presided over the organisation.

His research topics, represented by book titles, include German Baroque Poetry, German Theater Before 1750, Daniel Casper von Lohenstein's Historical Tragedies, The Rebel in Seventeenth-Century Tragedy, Mallarmé in the Twentieth Century, Romantic Drama, Romantic Prose Fiction, Contextualizing World Literature, Littérature comparée, littérature mondiale, Proust, Mann, Joyce in the Modernist Context, and Echoland. Readings from Humanism to Postmodernism (Brussels, 2006). He has contributed to the book Nonfictional Romantic Prose: Expanding Borders, edited by Steven P. Sondrup.

Living Streams: Continuity and Change from Rabelais to Joyce consists of essays written and published from 2004 to 2018, with a few alterations in the earlier ones. The chapters are divided into two major parts: Part One: The Joys of Vision and Rewards of Retrospection, and Part Two: Hindsighted (Post) Modernism and Polysemous Multiplexity.

Gillespie acknowledges himself to be a supporter of the view of the late Middle Ages and the Renaissance, rather than any earlier period, as the pinnacle of Western civilisation. On the brink of the postmodernist apprehension of an apocalypse and an imagined sea change of culture, consisting of an unforeseeable and radical transformation of the human condition, in this book especially but also in earlier ones he has undertaken the task of sifting out the golden core of printed literary culture, the fruit of the previous sea change five centuries ago in the wake of which we are still living. According to the text on the back cover:

This book examines how a long line of imaginative writers, starting from Rabelais and continuing over Cervantes and Sterne down to such modernists as Proust, Mann, Joyce, and Barth, has reaffirmed the picture of an enduring Western civilization despite repeated crises and transformations. The humanist capacity to recapture a sense of European greatness as exhibited in Antiquity 
was paralleled by and continued in the guise of newer vernacular works, achievements regarded as vital forms of a shared cultural rebirth. This was amplified most notably in the tradition of the ironic encyclopedic novel which surveyed the state of successive phases of culture. The evolving heritage and revitalization of the arts constituted main subject matters in the series of major self-conscious epochal movements, the Enlightenment, Romanticism, and Modernism, which Postmodernism reflexively now struggles to supersede.

The book includes abundant references to cultural motifs in the two millennia of Romance-Germanic literary tradition. The backbone of the approach is understanding the major Western literary masterpieces of the Gutenberg era, from Rabelais to Joyce, through the symbols from the beginnings of the JudeoChristian tradition, which in their turn are decoded biologically, as pathways to the forgotten dawn of humanity.

The implicit mission of the book apparently is to remind the readers of the present era of increasing electronic literacy of the importance of the legacy of the products of the early spread of printed books since the start of Renaissance in Western Europe. Gillespie is expanding the borders of the understanding of $15^{\text {th }}$ to $20^{\text {th }}$ century Western top fiction, basing his endeavour on his experience of hidden treasures of the imaginative literary art of the period, not of top fiction only nor only of fiction but achievements of creative literacy in general. As his main themes in this book, one could list drawing thematic connections between $20^{\text {th }}$ century masterpieces, especially of Joyce, with Renaissance, Baroque and Enlightenment works, especially in German; interpreting works through ancient archetypes and rituals, such as the primordial fall, the entrance into the otherworld and baptism through water; and long discussions of the position and role of the discipline of comparative literature in the present world, on the sociological background of the major global changes since the discovery of the Americas.

Gillespie writes that the literary masters of the early twentieth century were well aware of how since the days of Gutenberg, imaginative writings had come to replace the role of holy rites and rituals of the primeval eras. Thomas Mann is said to have overtly expressed that view. In the cathedral of cultural literary heritage, Joyce appears as a devout churchgoer, Proust as a priest, and Mann as a theologian. As to Joyce, piety can cohabit with vices, as Thornton Wilder has written about the Dubliner: "Joyce's belly was filled with bile and envy and resentment. The greater the rival, the more violent his denigration: sneers at Goethe, sneers at Shakespeare. He'd have turned on Ibsen, but Ibsen once wrote him a letter" (p. 153). It seems to be that precisely by writhing in the drab moments and aspects of the conscious and of life, the Irishman arrives at a redeeming synthesis: 
PILTER

Joyce brings us to the experience of rebirth and baptism despite the situation of our having slogged our way, with the narrator, through the piled up debris of the human story in the unfolding of the Viconian ages - despite our encounter with the sordid and weird aspects of our bodily and mental life, despite the burden of having admitted every wretched impulse or aberration which resides stubbornly collected in the unconscious. (p. 133)

That appears to make Joyce a Saint Paul of the literary pantheon of the Western canon.

Gillespie tries to grasp the scope and essence of world literature on the same ground that Goethe stood on, that is, from clearly a Western (Western European) standpoint but to cover territories which Goethe in his time (not a very distant past on Gillespie's time scale) was unable to observe. Gillespie has and displays excellent erudition in discussing both the literary achievements of the middle of the second millennium as well as $18^{\text {th }}$ to $20^{\text {th }}$ century literature of the United States. He is one of the exquisite experts on the works of James Joyce, but as he says in the Introduction, he has preferred not to reflect his concentration on Joyce in chapter titles, in order to maintain his chosen course of interpreting Joyce, Proust and Thomas Mann in the light of an earlier and even deeper strain.

Gillespie's work is congenial with the spirit of great works of literature, keeping a poise between abstract reasoning and attention to details and sensuality. The twelve chapters of the book form a balanced, highly informative, sufficiently compressed, enlightening journey through the complex of factors that the $20^{\text {th }}$ century classics and their present readers have inherited from the accumulated wisdom of previous ages which has produced some of the most noteworthy humorous encyclopedic volumes of writing. As such, the chapters represent Gillespie's creative act, based on his long record of reading and reflection, specifically for the readers of today. The chapter titles are the following:

Part One

Chapter 1: The Dangerous but Joyful Venture of Cultural Rebirth from Rabelais to Joyce

Chapter 2: Looking Through Windows of Time: Illustrative Moments of Vision in Literature since the Renaissance

Chapter 3: The World as Music: Variations on a Cosmological Theme

Chapter 4: Traveling into the Abyss

Chapter 5: Some Shape Shiftings of the Divine Feminine in Nineteenth Century Literature

Chapter 6: Peripheral Echoes: "Old“" and "New" Worlds as Reciprocal Literary Mirrorings

Chapter 7: North/South, East/West, and other Intersections 
Living Streams of World Literature

\section{Part Two}

Chapter 8: Swallowing the Androgyne and Baptizing Mother

Chapter 9: "Paradox Lust": the Fortunate Fall According to Joyce

Chapter 10: Ondts, Gracehopers, and Quarks; Joyce Never Gets Quit of Faust

Chapter 11: The Tantric Strain in Western Literature and the Arts Since Romanticism

Chapter 12: Newer Archaeologies of the Soul: By Way of a Conclusion

In Chapter Three, the author discusses the employment of the Pythagorean theory of the universe as music by writers since the Middle Ages with special focus on Arthur Schopenhauer who as a precursor of Wagner and Nietzsche anticipated the works of High Modernism. In Chapter Five, the shift of the image of the Divine Feminine from the figure of Virgin Mary to a "Venus in furs" during the 19th century is observed. For emerging writers, the shift along with the secularisation of natural sciences produced the uncomfortable sense of the doubleness of mother as not just a source of benediction but as a physical dominant. The doubleness of mother is connected with the uncanny realisation of the androgyne, a reality to be accepted on the road to maturation of the individual. A fateful encounter with the androgyne is depicted, for example, in the magic theatre episode of Hermann Hesse's novel Der Steppenwolf. In Chapter Nine, Joyce's novels Ulysses and Finnegans Wake are analysed as endeavouring an earthily ironic echo to John Milton's epics about Satan's rebellion and the fall and redemption of mankind. Chapter Ten focuses narrowly on Joyce's coinage of the word quark, later revived as a term in particle physics, which is actually a loan word from German and appears in Goethe's Faust. Gillespie hypothesises rather credibly that Joyce's use of the word may be traced back to the Irishman's youthful, imitative plans to write a direct match for Goethe's masterpiece. In Chapter Eleven, Gillespie employs the Hindu word tantra to characterise what he describes as an extreme state of tension in Western literature, other arts and mode of culture in general since Romanticism. He quotes the scholar Hugh Urban who defines tantra as "the most transgressive and violent path to the sacred", and gives a list of its contemporary expressions, including "perennial apocalyptic fears, gnostic hysteria, awareness of the dangers of the human imagination, ambivalent conviction in the world's materiality by a variety of self-styled realists, recurrent anarchic impulses, and outright nihilism" (p. 171). Among models of a positive alternative, Gillespie names Goethe. He writes:

Though personally not a Christian, Goethe elaborates a post-Christian mythic vision that encourages us to appreciate Christian symbolism, too, from an anthropological vantage, much as the poetic anthropologists and great novelists of the early twentieth century were soon to do. In effect, in Faust, Goethe liberated 
PILTER

paradigms and archetypes as poetic truth transcending prior religious and philosophic quarrels. The work Faust in covering more than three millennia rescues the human enterprise as a developmental saga. It opens a window onto our possibilities by reconstructing a larger cultural memory that possesses enormous and mysterious dimensions. We are challenged to embrace the evolved repertory which is the background of our own participation in time. (p. 161)

Gillespie shares the view of enthusiastic Goethe interpreters who regard Faust a Gesamtkunstwerk, "a one-of-a-kind epical work like Dante's Divina Commedia" (p. 160). With the same liberating trend, the author identifies Joseph Conrad and Thomas Mann, among others. He claims that Proust's Recherche approximates "a symphonic Gesamtkunstwerk" (p. 178). Touching upon the familiar theme of the double-edged nature of language and the limits of linguistic expression, Gillespie concludes the chapter with the idea of the cultural theorist and scholar of comparative religion Eric Voegelin who "came to perceive in the recent revolutionary period "a monomaniacal desire to force the operations of the spirit in history on the one line that unequivocally leads to the spectator's present"” (p. 171), that is, "a massive process of psychic deformation, wherein a destructive, delusionary experience of egophany displaces theophany" (p. 172). In agreement with Voegelin, Gillespie finds "the important twentieth century statements which possess honest breadth and redemptive potential" "not in any modern theorist but in the narrative works of Proust, Mann, and Joyce“ (p. 172).

What, then, is so redemptive in the printed linguistic artefacts by those authors and their likes to rescue their readers from the destruction by the massive processes of egophany? In evidence of the whole consciousness of humanity "as a circumscribed chain of events occurring during an interglacial warming episode of about ten to fifteen millennia”, Gillespie encourages his readers to look at "modernity's accrued anthropological knowledge thoughtfully in order to appreciate our situation as inheritors of a fragile civilization" (p. 176). The method of ekphrasis, ancient Greek for a literary description of a work of art, quasi-Homeric expressions of which the scholars of Joyce have found in his novel Ulysses, is one of the ways the reader's mind can be filled with grateful wonder. Thus, Gillespie invites us to refine our abilities to notice and appreciate what is timelessly valuable in the art of imaginative literature. 